\title{
NEW EVIDENCE ON THE LOGGERHEAD SEA TURTLE Caretta caretta (Linnaeus 1758) IN PERU
} Shaleyla Kelez ${ }^{1}$, Ximena Vélez-Zuazo ${ }^{1}$ y Camelia Manrique $^{1}$

\begin{abstract}
Resumen
La tortuga marina cabezona, Caretta caretta (Linnaeus 1758), tiene amplia distribución en el ámbito mundial. Sin embargo, en el Perú su presencia no estaba confirmada ni documentada adecuadamente. En esta nota, se presentan datos de restos de individuos de esta especie encontrados en caletas y puertos pesqueros, así como de individuos capturados incidentalmente durante faenas pesqueras con espinel. De esta manera, la presencia de esta especie en el mar peruano quedaría confirmada. Los individuos encontrados son juveniles y pertenecerían a poblaciones reproductivas cuyas playas de anidamiento se encuentran en el Pacífico Oeste.

Palabras clave: Tortuga marina cabezona, Caretta caretta, Perú,.distribución.
\end{abstract}

\begin{abstract}
The loggerhead sea turtle, Caretta caretta (Linnaeus 1758), is widely distributed in the worldwide scope. Nevertheless, in Peru its presence was not confirmed nor documented suitably. In these note, data of rests from this species' individuals found on inlets and ports as well as of individuals incidentally captured during fishing activities with longline is presented. In this way, the presence of this species in the Peruvian Sea would be confirmed. The individuals found are juveniles and could belong to reproductive populations belonging to West Pacific rookeries.
\end{abstract}

Key words: Loggerhead sea turtle, Caretta caretta, Peru, distribution.

\section{Introduction}

The loggerhead sea turtle, Caretta caretta (Linnaeus 1758), is widely distributed in tropical and subtropical waters in the Atlantic, Pacific and Indian Oceans, and Mediterranean Sea. In the Pacific, this species has been reported as far north as Alaska and as far south as Chile (Márquez, 1990). In Peru, however, $C$. caretta has not been officially documented, although there have been anecdotal reports since the 1950's [Carr, 1952; Koepcke, 1961; Moller-Hergt, 1976; Grimwood \& Whitmore, 1978 (in Frazier, 1979 p. 24); Aranda, 1989; Aranda \& Chandler, 1989]. Frazier in 1979 mentioned that if the loggerhead turtle is common in northern Chile it could be possible that this species could be present in southern Peru. Later publications neither confirm nor mention that the loggerhead turtle occurs in Peru (Hays-Brown \& Brown, 1982; Márquez, 1990; Carrillo \& Icochea, 1995; Morales \& Vargas, 1996). Despite this lack of documentation, the National Institute of Natural Resources (INRENA) in 1999 classified this species as vulnerable.

\section{Materials and methods}

During January and February 2002, a field survey to determine the current status of sea turtles along the southern coast of Peru was conducted. A total of 22 ports, inlets and beaches were surveyed. In each of these places, fishermen, authorities and members of the community were interviewed. All evidence of sea turtles in the area was recorded. The carapaces found were measured. The Curve Carapace Length notch to tip (CCLn-t) was taken in all the cases but the Straight Carapace Length notch to tip (SCLn-t) was taken when it was possible. All the carapaces were photographed.

From January to May 2003, on board observations during longline fishing activities, targeting "dolphinfish" Coryphaena hippurus and several species of sharks, were conducted. All the sea turtles incidentally captured were identified, measured, weighted, tagged, photographed and returned to the sea. The date, time and geographic position during the incidental capture was recorded.

\section{Results and discussion}

The results presented here are focused in the loggerhead sea turtle. Results on other sea turtles are excluded. In the 2002 survey, 39 individuals were recorded. Later analyses of these carapaces confirmed that three of them were $C$. caretta. The first carapace was found hanging as an ornament in a restaurant in Boca del Rio, Tacna. The turtle was reported to have been originally landed in the Vila Vila inlet (Figure 1). This carapace measured $57.8 \mathrm{~cm}$ SCLn-t and had only four lateral scutes, not common in this species but previously observed (Wyneken, 2001). The second carapace was found in Vila Vila inlet, Tacna, and measured $61.3 \mathrm{~cm}$ SCLn-t. According to the fisherman Luis Arce, he accidentally captured it 30nautic miles west offshore during his longline fishing activities targeting shortfin mako (Isurus oxyrinchus). The third carapace was found in the Coastal Laboratory of the Peruvian Sea Institute (IMARPE) in

\footnotetext{
${ }^{1}$ Grupo de Tortugas Marinas-Perú - gtm-perú y Asociación Peruana para la Conservación de la Naturaleza APECO. parque josé de acosta 187, Lima 17, Perú (Correo electrónico: skelez@yahoo.com)
} 
Ilo, Moquegua, and measured $63.9 \mathrm{~cm}$ CCLn-t. This carapace was purchased between 1996-97 in Atico, an inlet located to the north of Arequipa (M. Quiroz per. comm.).

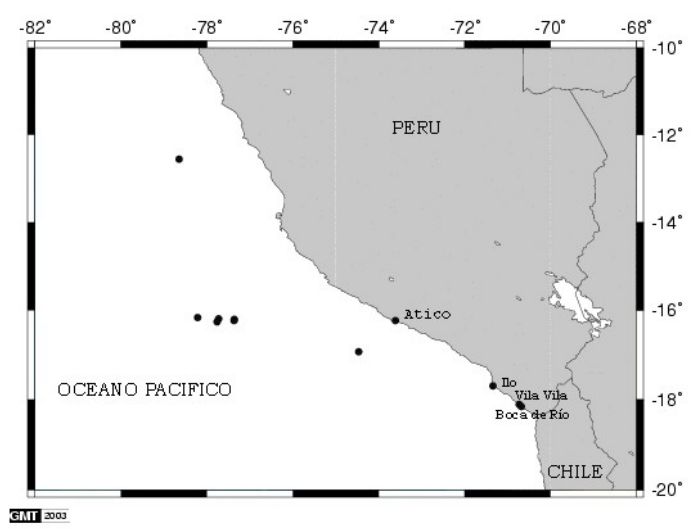

Figure 1. All the turtles (Caretta caretta) were found in central an southern Peruvian Sea.

During the longline fishing activities on-board observations, seven Caretta caretta were incidentally captured. All the turtles were found in central an southern Peruvian Sea (Figure 1). The average size of these individuals was $57.0 \mathrm{~cm}$ CCLn-t with a range of $48.5-62.5$, the average weight was $23.1 \mathrm{Kg}$. with a range of $15-28$. Five out of seven individuals were found with the hook in their mouths or throats. All the individuals mentioned in these note are juveniles because they are under $70 \mathrm{~cm}$ minimum size for adults (Márquez, 1990).

These findings confirm the previous anecdotal observations and other recent report (J. Alfaro pers. comm.) that document this species' presence in the southern coast of Peru. Since there are no known nesting beaches for $C$. caretta in the Eastern Pacific Ocean, these turtles likely originated from rookeries in the Western Pacific (Resendiz et al., 1998; Nichols et al., 2000).

\section{Conclusions}

On the basis of these findings, the presence of the loggerhead sea turtle in the Peruvian Sea in now confirmed and out of question. According to the size data obtained, the loggerhead turtle individuals are juveniles and would be migrating from rookeries in the Western Pacific, where they were born and will go back as adults to reproduce theirselves.

We recommend that further research be conducted to determine the specific rookeries of origin of these individuals, the population status, and the ecological role of the Peruvian marine environment in their life cycle.

\section{Acknowledgments:}

To Dr. Jack Frazier for his asserted observations and to Dr. Pritchard for one individual species identification. The authors wish to acknowledge use of the Maptool program for analysis and graphics in this paper. Maptool is a product of SEATURTLE.ORG. (Information is available at www.seaturtle.org). Funding came from AWARE Project, Idea Wild and the U.S. National Marine Fisheries Service.

\section{References}

Aranda C. 1989. Marine turtles in Peru. Marine Turtle Newsletter. 45: 8-9.

Aranda C. \& Chandler M. 1989. Las Tortugas Marinas del Perú y su situación actual. Boletín de Lima. 62: 77-86.

Carr A.F. 1952. Handbook of turtles: The turtles of the United States, Canada and Baja California. Cornell University Press, Ithaca.

Carrillo N. \& Icochea J. 1995. Lista taxonómica preliminar de los reptiles vivientes del Perú. Publicaciones del Museo de Historia Natural UNMSM (A). 49: 1-27.

Frazier J. 1979. Marine Turtles in Peru and the East Pacific. Office of Zoological Research, National Zoological Park, Smithsonian Institution. Unpublished manuscript.

Hays-Brown C. \& Brown W. 1982. Status of sea turtles in the Southeastern Pacific: Emphasis on Peru. In: K.A. Bjorndal (Ed.). Biology and Conservation of Sea Turtles. Smithsonian Institution Press. Washington, D.C. : 235-240.

Koepcke H. 1961. Synökologischen Studien an der Westseite der Peruanischen Anden, Bonner geographische Abhandlungen, Bonn.

Márquez M.R. 1990. FAO Species Catalogue. Vol. 11: Sea turtles of the world. An annotated and illustrated catalogue of sea turtles species known to date. FAO Fisheries Sinopsis $\mathrm{N}^{\mathrm{o}}$ 125, Vol. 11. Rome, FAO.

Morales V.R. \& Vargas P. 1996. Legislation protecting marine turtles in Peru. Marine Turtle Newsletter. 75: 22-23.

Moller-Hergt G.S. 1976. Análisis de la Situación Actual de los Mamíferos, Aves y Reptiles Silvestres del Perú. Biology Thesis, Universidad Nacional Agraria La Molina (UNALM), Lima, Perú.

Nichols W.J., Resendiz A., Seminoff J.A. \& Resendiz B. 2000. Transpacific loggerhead turtle migration monitored with satellite telemetry. Bulletin of Marine Science. 67: 937-947.

Resendiz A., Resendiz B., Nichols W.J., Seminoff J.A. \& Kamezaki N. 1998. First confirmation of a trans-Pacific migration of a tagged loggerhead sea turtle (Caretta caretta), released in Baja California. Pacific Science. 52: 151-153.

Wyneken J. 2001. The Anatomy of Sea Turtles. U.S. Department of Commerce NOAA Technical MemorandumNMFS-SEFSC-47. 